\title{
The Electoral Systems in SEE Countries: From Experiments to Consolidation
}

\author{
PhD. Afrim Krasniqi \\ University "Aleksander Moisiu"Albania \\ E-mail: afrimkrasniqi@gmail.com
}

\section{Doi:10.5901/mjss.2014.v5n7p569}

\begin{abstract}
This study analyzes the performance of the electoral systems in South Eastern European countries during the last two decades. It will argue that no other European region has experimented more with electoral systems than the SEE region. This has happened for many reasons: the lack of democratic experience, the nature of the new authoritarian regimes, the political interests of major parties and ethnical composition. Periodic changes that are made to the electoral systems are reflected by changes in the political systems. Countries where electoral systems have had more stability are those that have also had the most stable democracy levels. The study discusses the progress of the electoral process in each of the South Eastern European Country. It analyzes the features, common indicators, external and internal influences, as well as the formulas for translating votes into seats. The current study shows the tendency of regional countries to shift from the majoritarian electoral systems, introduced at first, to proportional electoral systems, as well as the new trends of specific formulas used to represent the ethnic communities and groups of citizens living abroad. While in the early 90's the electoral system had the tendency towards new political inflows, current tendencies are opposite. The traditional parties have a tendency to control the political representation system, while the new political inflows demanding political representation face obvious difficulties.
\end{abstract}

\section{Introduction}

After the collapse of the one-party political system, the establishment of new multiparty political systems was accompanied by a political wave of "constitutional construction" in each region, including the Central and Eastern Europe (Huntington, 1993). The new political elites sought to establish new political systems based on the new constitutions, but before doing so, they had to choose an electoral system that would generate new democratic parliaments. The choice of electoral system was accompanied by heated debates between political parties because of political interests and a lack of clarity about, and experience with, competitive electoral processes. The new electoral systems reflected the vision of the politics to create a system that would be as practical and competitive as possible. An important impetus was the strong relation between the electoral systems and their outcomes in the political system's ability to be efficient, and the support of citizens for democratic systems (Anderson, 1998), or, in other words, the power that electoral rules have which can make or undo a party and state (Taagepera, 2004). The two classical electoral systems basically produced two opposite parliamentary outcomes, hence two different political party systems. The majoritarian electoral system creates a bipartisan political system, while the proportional electoral system creates a multiparty political system (Duverger 1955). Choosing an electoral system cannot be a mechanical process using engineered calculations. The political system used and the level of representational democracy are dependent on the way the electoral systems work (Norris, 1997).

A number of scholars (Lijphart 1994, Mair 1990, Ware 1996, Norris 1997, Taagepera and Shugart 1989, Birch 2001, etc.) have classified the main factors that influence the choice of an electoral system. Among those factors are the local and global ones. The global factors include the number of inhabitants, the size of electoral districts, the voting structure, the electoral threshold, the number of seats in the parliament, the nature of the candidate nomination lists, etc., while the local factors include also the ethnic composition, geographic distribution, political culture, and the aim towards the type of political system demanded. The Venice Commission (2002) highlights five main principles of the electoral heritage in Europe: general, equal, free, secret and direct voting. These principles are insufficient, however, if they are not accompanied by the implementation of a set of minimal rules. These rules have to be such as to guarantee the credibility of the electoral process. Adhering to the set of basic rules, the stability of the regulations, the absence of any possible claim for manipulation and the effective implementation of the law procedures remain the prerequisites for the elections to comply with the principles established by the Venice Commission. 


\section{The First Electoral Systems: A Tendency towards Majoritarian Electoral Systems}

The region of South Eastern Europe offers a wide variety of electoral models, and ethnic, religious and political features that make it possible to test almost all the possible electoral models. The new democracies of South Eastern Europe do not have a rich tradition or a positive experience in the implementation of direct democracy, but they already have great experience with the implementation of majoritarian electoral systems, mixed voting systems and proportional voting systems. During the last 20 years, each country has changed its electoral system at least once, and there are countries (such as Albania) which have experimented with all the main electoral alternatives: majoritarian systems, mixed systems, and proportional systems. This very fact, that is, the continuous changes to the electoral systems in this region, is an indicator of the fragility of elections as an institution of political and civic representation. It is in contrast to the nearly agelong British, American or German electoral models, which have remained the same, and established an effective electoral tradition through public and political support.

During the 1920's and 1930's, the Balkan states had minimal experience with both functional political parties and a competitive electoral system. The shift to authoritarian regimes was accompanied by cessation of competitive elections, banning of political parties or formalization of the majoritarian electoral system with nomination lists imposed by the regime. It is no coincidence that the electoral systems during the communist regime in these countries were majoritarian. This is the legacy the new elites faced in the early 1990's, in their efforts to establish a new competitive and effective political system. Based on this legacy, on tradition and on public expectations, most of the countries remained faithful to the model of majoritarian electoral system. Another important reason for this choice was the fact that the communist regimes themselves felt stronger when individuals, rather than political party platforms, ran against each other. Albania is a typical example. In 1991, the communists lost all the major cities in proportional elections but they won all the suburban areas and rural areas. Hence, they provided themselves with the necessary seats number for a strong government derived by elections under a majoritarian electoral system. Such practices have been established in other countries of the region, too, especially in Bulgaria, Romania and in some Republics of the former Yugoslavia.

Regarding the performance of the electoral systems in the last two decades in the South Eastern Europe, it has been accepted that the application of electoral systems changed gradually moving from the majoritarian nature of the first systems to the proportional electoral models (Nohlen, 2007). In the early years of the transition period, the majoritarian electoral systems were introduced as two-round voting. Later there was a shift to mixed electoral systems and, in the last phase, to the largely proportional electoral system. This process has passed through three phases:

The first phase is related to the period of political system change, "a phase in which the uncompetitive elections were replaced by competitive elections" (Nohlen, 2005). At this stage, the ex-communist political forces managed to survive the changes. They even managed to strengthen their representative position. In the first political elections, the communist forces ran against a political opposition that was still fragile and relatively competitive. This situation of the opposition favored them in the subsequent process of bilateral discussions on the new electoral law. Albania and Bulgaria are a typical example.

The second phase of electoral reforms is associated to the consolidation phase of the transitional period (Grotz $e$ Muller, 2011). In all countries, reviewing the legislation and electoral models is still popular, mainly due to the changes of the political interests of the parties that constitute the majority in Parliament or the resentment of opposition parties. Amongst the new electoral models, the mixed ones prevailed, with a tendency toward the proportional representation. The changes were followed by the establishment of an electoral threshold, which was a safety measure for keeping the local initiatives and separatist or clientelistic parties away from the Parliament, with a symbolic support in the Parliament. The electoral threshold and establishment of a rapport between the parliamentary mandates and seats obtained under the proportional electoral system had significant impact on the quality of the new Parliament as well.

The new electoral systems also faced the dilemma of determining the fixed number of the rapport between the seats obtained under the majoritarian part of the electoral system and those obtained under the proportional part of it. Initially, only countries like Albania had a fixed number of proportional seats. In Albania, in the elections of 1992 and 2001, 100 seats were elected under the majoritarian electoral system, while 40 seats were elected under the proportional electoral system. In 1996, this rapport was corrected, establishing 115 seats obtainable under majoritarian electoral system and only 25 under proportional electoral system. The next year, the system underwent another change. The number of seats obtained under proportional electoral system rose from 25 to 40 , whereas the number of deputies in the Parliament rose from 140 to 155 (Krasniqi, 2009). In the rest of other countries, the number of seats obtainable under proportional electoral system varied depending on other indicators, such as the number of seats won under the majoritarian electoral system, participation in the election, etc. During the years 1996-1998, Macedonia also applied a mixed electoral system, according to which 85 parliamentary members were elected in electoral districts under the 
majoritarian electoral system, and 35 members were elected from proportional national lists (IPU, 2012).

Croatia also made changes to the system. In 1990, it introduced a two-round majoritarian electoral system. In 1992, it introduced a mixed electoral system under which 60 seats were obtainable under the majoritarian electoral system, and the same number of seats was obtainable under the proportional electoral system. In 1995, it increased the proportional percentage leaving only 28 seats that were obtainable under the majoritarian electoral system, and established an electoral threshold of $5 \%$ (IPU, 2012). For the first time the system gave the Croatians living abroad the right to elect deputies. Romania also originally introduced a majoritarian electoral system but in 1991, it switched to regional proportional electoral system, which was preserved throughout the years 1992-1999 (IPU, 2012) with very few changes done to it. In Bulgaria, according to the electoral law of April 2001, amended in 2009, 31 electoral districts vote under majoritarian electoral system, and 209 deputies are elected under proportional electoral system with closed lists (OSCE/ODIHR, 2009), while the electoral threshold is $4 \%$. In 1990, Serbia applied the majoritarian electoral system while the radical change took place in 1992 when it switched from majoritarian to proportional electoral system, hence the number of electoral districts rose from 9 to 29 (Goati, 2000). Montenegro has applied duplicated systems, a system in its own context and another system in the federation context. In Yugoslavia, elections were held under a mixed electoral system: a proportional electoral system (in Montenegro) and a majoritarian electoral system (in Serbia). In 1998, Montenegro amended the law, thus introducing also the majoritarian electoral system, which led to the victory of all progovernment candidates for Federal Assembly (Blanc, 2006). Whereas in elections in the Republic context, in the mid1990s, Montenegro also begun to apply a proportional electoral system with one national electoral district and a threshold of $3 \%$ (OSCE/ODIHR, 1998).

The third phase of electoral systems' configuration took place during the years 2000-2003. During this period, almost all SEE countries made new, mainly technical, changes to the electoral systems and formed a model-system, which, with very few exceptions (such as Albania) is still applicable in these countries. Table 1 shows the changes to the configurations of the electoral systems in the countries of Central and South Eastern Europe during the last two decades. As it can be seen from the table, the number of majoritarian electoral system and that of proportional representation was almost equal (considering the existence of Yugoslav Federation or Czechoslovakia). With some differences (Albania, Macedonia, Croatia, etc.), in the countries where the electoral systems were modified, the electoral systems' models from the first transitional phase dominated again in the second political elections. During the second decade of the transitional period, only Albania and Hungary had introduced mixed electoral systems, while other countries moved to proportional electoral systems.

Table 1: Electoral Systems in the Central and South Eastern European countries ${ }^{1}$

\begin{tabular}{|l|c|c|c|c|c|c|}
\hline Country & $1989 / 90$ & $1991 / 92$ & $1996 / 98$ & $2000 / 02$ & $2005 / 06$ & $2009 / 10$ \\
\hline Albania & Maj. & Mix & Mix & Mix & Mix & Prop. \\
\hline Bosnia & Mix & - & Prop. & Prop. & Prop. & Prop. \\
\hline Bulgaria & Mix & Mix & Mix & Prop. & Prop. & Mix \\
\hline Croatia & Maj. & Mix & Prop. & Prop. & Prop. & Prop. \\
\hline Czech Republic & Prop. & Prop. & Prop. & Prop. & Prop. & Prop. \\
\hline Hungary & Mix & Mix & Mix & Mix & Mix & Mix \\
\hline Kosovo & - & - & Prop. & Prop. & Prop. & Prop. \\
\hline Macedonia & Maj. & Maj. & Mix & Prop. & Prop. & Prop. \\
\hline Montenegro & Maj. & Prop. & Prop. & Prop. & Prop. & Prop. \\
\hline Poland & Prop. & Prop. & Prop. & Prop. & Prop. & Prop. \\
\hline Romania & Prop. & Prop. & Prop. & Prop. & Prop. & Mix \\
\hline Serbia & Mix & Mix & Mix & Prop. & Prop. & Prop. \\
\hline Slovakia & Prop. & Prop. & Prop. & Prop. & Prop. & Prop. \\
\hline Slovenia & Prop. & Prop. & Prop. & Prop. & Prop. & Prop. \\
\hline
\end{tabular}

In the end of the second decade of the transitional period, only Hungary has continued to use a functional mixed electoral system. Albania switched to a proportional electoral system; Bulgaria has given its mixed electoral system some apparent nuances and characteristics from proportional electoral systems. In contrast, Romania moved in the opposite direction - it chose a new electoral system model - a mixed majoritarian electoral system with proportional correction.

1 IPU, The PARLINE database. (2012). The data are obtained for every country, and processed and analysed by the author. 


\subsection{Electoral formulas: D'Hondt method is dominant}

Different experiments with electoral systems were products of parliamentary voting. Only Romania tried to make an exception, in its last initiative for a referendum on the issue of the electoral system. In November 2007, in the day of European elections, a referendum with "yes" and "no" alternatives was held, while the question was: Do you agree that, starting from the next elections for the Parliament of the Republic of Romania, all deputies and senators should be elected under the majoritarian electoral system with two rounds? The referendum failed because the participation was 26 $\%$, of which $81 \%$ voted in favor of the proposal².

When states tended to switch to proportional electoral models, the electoral debates focused on the formula of translating the votes into seats. Among some classical formulas, the D'Hondt method was the most dominant. Table 2 illustrates the methods used for calculating the proportional votes in all the Eastern European countries. According to the D'Hondt method (KIPRED, 2011): the seats won in an electoral district are not allocated only by the percentage won by a party - so this formula doesn't translate the votes proportionally but it calculates the highest averages of the number of votes received by parties. If a given electoral district offers 10 seats, then the total number of votes received by each party is divided by numbers from 1 through 10. After this dividing process ends, the seats in the Parliament are won by the parties that have the ten biggest numbers. The D'Hondt formula advantages parties or big coalitions (which might be two or three, depending on the country) and disadvantages smaller parties The bad outcomes on the smaller parties are reduced, however, if the electoral districts are big and offer more seats, thus increasing their chances to win seats in electoral districts.

The second most used method is Sainte Laguë, according to which, "the number of seats is defined proportionally by a quotient. The total number of votes received by a party, is divided by the number of seats that party has allocated so far. This number is initially 0 for all parties. The party having the highest quotient gets the next seat allocated and its quotient is recalculated, given their new total number of seats until all seats are allocated. As in the case of D'Hondt formula, this formula favors the big parties" (KIPRED 2011).

Table 2: Calculation formulas applied in the South Eastern European Countries during the $1990-2011$ period for allocating seats (IPU)

\begin{tabular}{|l|c|c|c|c|c|c|}
\hline Country & 1991 & 1992 & $1996 / 97$ & 2002 & 2005 & 2010 \\
\hline Albania & - & Hare & Hare & Hare & Hare & D'Hondt/S.Lague \\
\hline Bosnia & - & - & D'Hondt & Sainte Laguë & Sainte Lague & Sainte Laguë \\
\hline Bulgaria & D'Hondt & D'Hondt & D'Hondt & D'Hondt & D'Hondt & D'Hondt \\
\hline Croatia & - & D'Hondt & D'Hondt & D'Hondt & D'Hondt & D'Hondt \\
\hline Kosovo & - & - & - & D'Hondt & D'Hondt & D'Hondt \\
\hline Macedonia & - & - & - & D'Hondt & D'Hondt & D'Hondt \\
\hline Montenegro & D'Hondt & D'Hondt & D'Hondt & D'Hondt & D'Hondt & D'Hondt \\
\hline Romania & - & Hare/D'Hondt & Hare/D'Hondt & Hare/D'Hondt & D'Hondt & D'Hondt \\
\hline Serbia & - & D'Hondt & D'Hondt & D'Hondt & D'Hondt & D'Hondt \\
\hline Slovenia & D'Hondt & Hare/D'Hondt & Droop/D'Hondt & Droop/D'Hondt & Droop/D'Hondt & Droop/D'Hondt \\
\hline
\end{tabular}

The comparative analysis of the table shows that in the first elections, there were different alternatives of calculation (D'Hondt, Hagenbach-Bischof, Hare-Niemayer); in the second elections, the D'Hondt formula began to dominate, while in the mid-90s for the first time, Sainte-Laguë method was also introduced. In recent elections, except for Hungary and Bosnia where different calculation formulas are still unchanged, the D'Hondt formula has been applied in 13 countries. Countries like Montenegro, Slovenia, Croatia, etc., have applied almost the same formulas since the first or the second political elections.

In some countries, where there is a separation between the national and local proportional calculation, or between the votes of competitive electoral subjects and the constituent subjects in a political coalition, two different formulas are simultaneously applied.

\footnotetext{
2 Ogaru, Roberta-Manuela. (2011). The Effects of the 2008 Romanian Electoral System Reform:when the Reformation Converts to Counter-Reformation, Centre for Legislative Studies, Bucharest, 5.
} 


\section{Stable Systems for Stable Governing}

After two decades of continuous change to electoral systems, most of the South Eastern European countries reached consensus on adopting new systems, which were tested at least in one election and designed to not change in the coming elections. Some of the countries, including Albania, integrated the model of electoral system into the Constitution, thus creating a legal and political shield against any dissatisfaction or request to review and modify the system.

There are several electoral systems and distinctive properties in the electoral legislation of the analyzed countries of South Eastern Europe. The comparative analysis of each country's electoral models shows that the proportional system is dominant, in contrast to the dominant systems during the 1990s. If we refer to the countries of the region, we notice that the proportional electoral system models are dominant, having tactical differences across the countries. In 2009, in Bulgaria the pure proportional electoral system was corrected by introducing a model with a proportional nature, but $13 \%$ of the seats were elected under the majoritarian electoral system (IPU 2012). In Croatia, part of the change was also the division of the country into 10 electoral districts, each having 14 deputies, the creation of a separated district for 12 deputies that would be elected by Croatians abroad, and the creation of another special district for 8 deputies from national minorities. Even in this case, the electoral threshold of $5 \%$ at electoral district level was preserved (OSCE/ODIHR, 2011). In Macedonia, according to the recent legal changes, the Parliament consists of 123 deputies, 120 of which are elected under proportional regional voting system (6 districts with 20 deputies each), and closed lists, and 3 other deputies are elected under majoritarian electoral system by Macedonians living around the world (OSCE/ODIHR, 2011). In Montenegro, the country is considered as one single electoral district; elections are held under a proportional electoral system; the electoral threshold is $3 \%$; closed lists' system has been adopted, and 5 seats are reserved for the Albanian community (OSCE/ODIHR, 1998). In Slovenia, the House of Commons is comprised of 90 members, who are elected under proportional electoral system; there are 8 electoral districts, each having 11 deputies, and two seats are reserved for the Hungarian and Italian national minorities (OSCE/ODIHR, 2011). In contrast to some other proportional electoral system models, the Slovenian one is proportional preferential, that is, each voter can vote for the party or the candidate he or she likes. In 2000, the electoral threshold for the 88 deputies was raised from 3.2 to $4 \%$, but this threshold is not applied in the case of the minority groups. In 2003, Serbia also made changes to the electoral system, introducing the d'Hondt formula to calculate mandates (IPU 2012). Romania is the only country that switched from a proportional electoral system to a mixed one - representative and majoritarian electoral system. In the new electoral system, elections in about 40-43 electoral districts continue to be held under the proportional electoral system, the national electoral threshold is $3 \%$, and the local threshold is $5 \%$, while about 327 MPs are elected under majoritarian electoral system.

In the Romanian model, the electoral threshold does not apply to national minorities, and according to the electoral law, such groupings have reserved seats in the Parliament for which they run against themselves. The Romanian electoral model is designed in such a way that one deputy is elected by, and responsible for, 70 thousand voters, while a senator is elected by, and responsible for, 160 thousand voters. Each electoral district must have more than 4 deputies and 2 senators, thus guaranteeing a balanced representation of all regions (Jula, 2010). In 1996, in Romania 27 political parties and 15 minority subjects were represented in Parliament. This was one reason the Romanian lawmakers demanded control mechanisms on fragmented political representation, by setting an electoral threshold of $5 \%$ for political parties, and plus $3 \%$ for each second party in the coalition until the threshold reaches $10 \%$. Consequently, after the 2000 elections, only 6 parties and 18 ethnical groups have been represented in Parliament.

The same changes to the electoral system were made in Albania during 2008-2013, in order to avoid having a large number of parliamentary political parties. The Parliament elected in the 2005 elections consisted of 11 political parties; this number rose to 13 as two new entities emerged in Parliament. In the 2009 elections, due to the shift from mixed electoral system to regional proportional electoral system with no national correction, from 35 competitive entities only 6 political parties were represented in Parliament, three of which were symbolically represented by one deputy each. Because of the electoral system, parties receiving a minimal number of votes $(4,500)$ at an electoral district level won a seat in the Parliament, while political parties receiving about 29 thousand votes at national level were left outside the Parliament (Krasniqi, 2012). In the 2013 elections, the number of parliamentary parties grew and no single political party could establish a government. The regional proportional electoral system made it necessary to create coalitions, and punished the third-group political parties, that is, parties that had not been part of either of the two big coalitions. The average number of votes for a mandate for the big parties was approximately 9 thousand, while third-group political parties did not win any seat, even though they had obtained 30 thousand votes at national level.

In the former Yugoslav countries, in their first political elections, it has been shown that four Yugoslavian republics (Croatia, Serbia, Macedonia and Montenegro) adopted a majoritarian democracy, thus having a dominant party in both 
Parliament and political life (Fink-Hafner... 2011). In contrast to the Albanian, Croatian, Serbian, etc. model where single political parties managed to win the majority in the respective parliaments elected in the first, second and third elections, that is, the necessary seats for drafting electoral laws, Slovenia is an exception. It has established a political and electoral system that prevents any single political party or political actor from winning the majority in Parliament, because in such a case they could take advantage of the electoral system or impose a new one. In Slovenia, in the 2004 and 2008 elections, seven parties were represented in the Parliament, one less than in 2000 , thus creating a mature political system (Fink-Hafner.. 2011).

According to the analysis of the political representation under proportional electoral systems, Poland, Slovakia, Slovenia, Kosovo, Latvia, Estonia and the Czech Republic have adopted opened proportional lists, while Albania, Montenegro, Romania, Bulgaria, etc, have applied a system of closed lists. The electoral system appears in several main formats or models, such as local proportional electoral system, national proportional electoral system, or proportional electoral system with or without an electoral threshold. The concept of electoral district is very significant, too, since it might be a balanced or a non-balanced representation unit, depending on territorial division or number of inhabitants. However, the dominating models are the local and national proportional electoral systems, and mixed models with proportional correction.

1. National proportional electoral systems with one single electoral district (Kosovo, Montenegro, and Serbia). In these countries, it is created a single electoral district, and voters vote for the future parliamentary members from national party lists. In Montenegro, the electoral threshold is $3 \%$, and five seats are reserved for national minorities (OSCE/ODIHR, 2009). In Serbia and Kosovo, the electoral threshold is $5 \%$, but in contrast to them, in Kosovo there are reserved quotas for minorities and every voter votes for up to 5 candidates from the open proportional lists. The Kosovo model is close to the Slovakian one, while the Serbian model is a classical national proportional electoral system.

2. Regional proportional electoral systems (Macedonia, Albania, Croatia, and Slovenia). Voters vote for their preferred candidates from the voting list, and the votes for the candidates are at the same time votes for parties. The electoral threshold plays a specific role because it nullifies the votes obtained at national level, which have not been represented in the electoral districts/areas. The application of this system in different countries has special characteristics. For example, in Croatia there are 10 electoral districts, each having 14 members; closed lists and an electoral threshold of $5 \%$ (OSCE/ODIHR, 2012). Two special districts are reserved for Croatians living abroad and minorities. In Slovenia, the same system is applied in 8 electoral districts, with a threshold of $4 \%$, and according to the electoral law two seats are reserved for ethnical minorities. In Albania, the minimal threshold is $3 \%$, closed lists are applied, and the elections are held in 12 electoral districts with unbalanced numbers of seats ranging from 4 to 32. In Macedonia, the 6 electoral districts, each having 20 seats, are still preserved, whily 3 seats in the Parliament are reserved for Macedonians living abroad. Macedonia is the only country that does not apply any electoral threshold.

3. Mixed systems (majoritarian plus proportional). This system continues to be applied in Bulgaria, where the last change took place in 2009 , on the eve of parliamentary elections, by adopting a mixed electoral system; 209 deputies are elected according to the proportional electoral system in 31 electoral districts, and 31 are elected in these electoral districts under a simple majoritarian electoral system. The electoral threshold, which uses the Hare-Niemeyer formula, was set at $4 \%$ at the national level as a prerequisite to benefit from the allocation of proportional seats.

From the electoral models in South Easter Europe, the case of Bosnia is special. The electoral system in Bosnia is very complicated mainly due to the triple-ethnical nature of representation (OSCE/ODIHR, 2010). In the last parliamentary elections (2010), 39 different kinds of ballots were present, 21 for the elections at national level, of which each voter votes with four different ballots. At the federal level, voters vote for 42 members of the House of Representatives, and 3 members of Bosnian presidency. The parliamentary elections are held under the proportional electoral system; 21 members in 5 electoral districts. According to the law, the allocation of 7 remainder seats is calculated under the national proportional electoral system. 14 parliamentary members are elected in the Serbian district of Bosnia, 9 from the electoral districts and 5 from the proportional lists as compensation for the parties receiving more than $3 \%$ of the votes. At federal level, voters elect 98 members, and 10 members to the local assembly. In the Serbian part, they vote for 83 members of National Assembly, the President and two vice presidents, always under the majoritarian electoral system. 


\section{Current Systems and the Prospect of Electoral Systems in South Eastern Europe}

In some countries in the region, there are political parties and organizations that suggest the need for changes to the electoral systems. Blaming the system and not the political will for the correct implementation of the electoral law, in some countries (Albania, Kosovo, Macedonia, Serbia, Romania, Bulgaria and Slovenia) the critics suggest that their countries apply some electoral systems that previously have not yielded good results in the other neighboring countries. For example, Albania demands a proportional system with open lists, which is applied in Kosovo, while Kosovo demands the opposite: the shift to proportional electoral system with close lists or majoritarian electoral system, which have been applied in Albania without any significant success.

The expansion of voting (presidential vote, parliamentarian vote, local vote, European vote), the expansion of voting base (voting right for emigrants and groups of citizens living abroad), and special constitutional obligations in some countries (quota for minorities in Kosovo, Bosnia, Croatia, Montenegro, etc.) create a complex net of factors, on which the decision making regarding the electoral systems should be focused. Initiatives for changes are faced with other practical difficulties as well. For example, legal changes are decided upon in Parliament and they require the consensus of the main political parties. Since all over the region the bipartisan system has shifted to multi-party system - which means that there are new inflows and fragmentation of traditional political parties - the old political parties themselves are interested in using the veto against changes that could bring the loss of the importance of their dominant role in the political life. Thus, in Albania, Macedonia, Kosovo, Montenegro, etc., the main political parties are against drastic changes to the systems because under the current systems they remain the dominant factors in political life.

The third important trend in the region of South Eastern Europe is the use of electoral rules to limit the new political inflows. If the political models, such as the Romanian or Albanian ones, are compared to the western models, the odds of the two Balkan countries to establish a political party are much smaller than in any Western country. Establishing the criteria of providing thousands of preliminary signatures or signatures in more than one electoral district, the obligation to collect signatures in every electoral process, or the support for a high electoral threshold, are some of the real obstacles to the liberalization of political competition in this region. Innovations, such as the success of third and new political forces in Slovenia, Bulgaria, Serbia, Kosovo or Albania, are evidence that voters are seeking new mechanisms and action spaces. In the future, this tendency is expected to be intensified, and the countries are expected to be under pressure to review the rapport between citizen demand for more representative democracy and traditional interests of political parties to maintain the status quo.

Another significant element is the practice followed by most countries in the region to state the electoral system in constitutions. Whenever debates on changes take place, the use the constitutional power makes it impossible for the political parties to make amendments to the constitution. Such a process requires a lot of energy, time and a wide political consensus. The more the years pass by and the more the states create a mature political behavior profile, amendments to the constitutions will be increasingly rare. The solution is to remove the establishment of electoral system from constitutions and apply the council of the Venice Commission for adopting new electoral systems in long terms, not for the next elections, but for the second and third elections, when no political party will be able to know whether they will be in power or in opposition.

On this basis, there are enough indicators to make us believe that the current electoral systems are not expected to undergo changes in many years to come. It is likely that there will be a demand from political and civil groups, and suggestions from technical reports on electoral systems, but the real change will be able to take place only when it suits the political ambitions of the two main political parties, as well as their conviction that the change will not undermine their control on the political system and political decision making.

\section{Conclusions}

During the last two decades, no other region of Europe has experimented more with electoral systems than the South Eastern Europe region. The lack of democratic experience, the minimal political culture, and the use of electoral rules to serve political interests of next majorities have created a series of trial electoral systems in all the countries of the region, and the impossibility for one single system to reach maturity. Initially almost every country introduced majoritarian electoral systems that later were replaced partially or completely by electoral systems that were of a proportional representation nature, so there was a shift from individuals to political parties, from direct to indirect elections, from the trust in the citizen to a contract between citizens and political parties. This shift has been accompanied by experiments with proportional formulas and electoral administration, heated debates on the quality and integrity of the system, 
parliamentary boycotts and even debates of an ethnical nature - all of these indicators affect the fragility of the electoral system and the political system.

In the end of two experimenting decades, the region of South Eastern Europe is more aware of mature electoral reforms, increased representation quality, and achievements of maximal voting standards, which are consistent also with the aspirations of every country for active membership in the European Union. The phenomena of ethnical representation, electoral funding or quality of independent electoral administration are still problematic. However, the competition process and vote counting have gained high credibility in comparison with any other previously experienced period in the history of SEE. In 2014, there is no country in the region, which contests the elections, and the election results are accepted by all political parties. This is a significant development compared to the mid-1990s. This is another indicator of citizens and integration process influence in creating a new political culture, for more standards and functional democracy.

\section{References}

Anderson, Ch. (1998). Parties, Party Systems, and Satisfaction with Democratic Performance in the New Europe, in: Political Studies, Special Issue, 574-576.

Birch, S. (2004). Electoral Systems and Political Transformation in Post-Communist Europe. New York, NY: Palgrave Macmillan.

Fink-Hafner, D \& Lajh, D \& Krašovec, A. (2011). Electoral Engineering and its Impact in the Former Yugoslav

Republics, in Politics in Central Europe, Volume $7 \mathrm{Nr}$, Prague, 14/15.

Grotz, F. \& Müller, F. (2011). Regierungssysteme in Mittel- und Osteuropa die neuen EU-Staaten im Vergleich, Wiesbaden: VS Verlag, 3.

Jarrett B, \& Aanund H, \& Kåre V. (2006). State Structure and Electoral Systems in Post-Conflict Situations, IFESIQuality AS, July 7.

Jula, N. (2010). Regional analyses of voting behaviour in Romania-Local, general and presidential elections, RJRS, Vol.4, nr.2. 65-66.

Kitschelt, H, \& Zdenka M, \& Radoslaw M, \& Gabor T. (1999). Post-Communist Party Systems: Competition, Representation and InterParty Cooperation, Cambridge: Cambridge University Press.

Krasniqi, A. (2009). Zgjedhjet ne Shqiperi 1991-2008 [Elections in Albania: 1991-2008], Konica, Tiranë, 28.

Krasniqi, A. (2009). Zgjedhjet dhe Administrimi zgjedhor në Shqiperi [Elections and Electoral Administration in Albania], ACFR/AAIS, Tiranë

Krasniqi, A. (2012). Sjellja zgjedhore dhe identifikimi i votës në Shqipëri [Electoral behaviour and vote identification in Albania], "Studime Politike", IS, Tiranë.

Lijphart, A. (1994). Electoral Systems and Party Systems. Oxford University Press.

Mair, P. (1990). The West European Party System. Oxford University Press.

Norris, P. (1997). Choosing Electoral Systems: Proportional, Majoritarian and Mixed Systems, (Harvard University), Science Review Vol 18(3), July 1997: 297-312.

Norris, P. (2004). Electoral Engineering: Voting Rules and Political Behavior. Cambridge University Press.

Nohlen, D \& Catón, M \& Philip S. (2007). Elections in Europe, Oxford Uni Press.

Nohlen, D. (2005). Wahlrechtsentwicklung im internationalen Vergleich. The Development of Electoral Systems in Comparative Perspective, in ÖZP, Wienna, 1, 11-26

Taagepera, R. (2004). Votat dhe mandatet: efektet dhe percaktuesit e sistemeve zgjedhore [Seats and Votes: The effects and determinants of electoral systems], Ilar, Tiranë.

Ware, A. (1996). Political Parties and Party Systems. Oxford University Press.

International Organizations Reports:

IPU, The PARLINE database. (2012). Electoral Systems, Source: www.ipu.org/parline-el.

KIPRED. (2011). Krahasim i sistemeve zgjedhore në rajon [A Comparison of Electoral Systems in the Region], Prishtinë.

OSCE/ODIHR. (2006-2012). Election Observation Mission in Croatia, Albania, Bosnia, Kosovo, Serbia, Romania, Bulgaria, Montenegro, Slovenia, Slovakia, FYROM.

Venice Commission. (2002). Kodi i praktikës së mirë në çështjet zgjedhore [Code of good practice in electoral matters], Opinion No.190, CDL-AD (2002) 23 rev, Strasbourg. 